\title{
Diskurzus a területi tőke koncepciójáról. A Regionális- és Gazdaságtudományi Doktori Iskola workshopja
}

\section{Discussion about territorial capital. A workshop of the Doctoral School of Regional and Economic Sciences}

\author{
CZAKÓ KATALIN
}

CZAKÓ Katalin: PhD-hallgató, Széchenyi István Egyetem, Regionális- és Gazdaságtudományi Doktori Iskola, Győr; ckatalin@sze.hu

Katalin CZAKÓ: PhD student, Doctoral School of Regional and Economic Sciences, Széchenyi István University, Győr; ckatalin@sze.hu

\section{Bevezetés}

A Regionális- és Gazdaságtudományi Doktori Iskola tudományos programja 2004-ben indult a győri Széchenyi István Egyetemen. Az iskola több mint 10 éves célja a közép-európai térség jelenlegi és jövőbeli együttműködési irányainak feltárása, a hozzájuk kapcsolódó ösztönző és gátló tényezők értékelése. Az iskola másik kiemelt célja a gazdasági, társadalmi és intézményi kapcsolatok beágyazódásának vizsgálata. A jelenlegi és jövőbeli térségi együttműködések kutatása mellett az iskola törekszik arra, hogy a kooperációk aktív résztvevője legyen. Ennek érdekében folyamatosan keresi a kapcsolódási pontokat a hasonló kutatási témával rendező, országon belüli és kívüli tudományos műhelyekhez (RGDI 2015). Az iskola fennállása óta több olyan együttműködési platformot is sikerült kialakítani, melyek stabillá váltak és mára nélkülözhetetlenek a magas szintű kutatási tevékenység eléréséhez. Ezek közül meg kell említeni a kétévente megrendezett, rendszeresen nagy érdeklődésnek örvendő Fiatal Regionalisták Konferenciáját vagy az évente megrendezett Kautz Gyula Konferencián futó önálló szekciókat. Évente több alkalommal van lehetőségünk tematikus workshopok rendezésére, melyeknek érdeklődő hallgatósága és előadói köre minden esetben reprezentálja az iskola széles kapcsolati rendszerét. Ennek szellemében rendeztük meg a Diskurzus a területi tőke koncepciójáról című

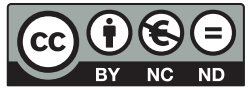


workshopot a Széchenyi István Egyetemen, 2015 júniusában. A workshop a regionális tudomány egyik legtöbbször emlegetett fogalma, a területi tőke köré épült, a rendezvényre a témában kutató szerzőket hívtuk meg. A workshop célja az volt, hogy a kutatók bemutassák Roberto Camagni területitőke-koncepciójával (1. ábra) kapcsolatos módszereket, kritikai észrevételeket, a használhatóság kérdését, a mérhetőséget, az immateriális tőkeelemek fontosságának kérdését és az elképzelés gyakorlati mérésekben betöltött szerepét.

A találkozó kiemelt célja volt egyben, hogy a témakört kutató hálózat kialakítását indítsa el. A széles körü érdeklődés mellett a rendezvény sikerét az is mutatja, hogy mind az előadók, mind a hallgatóság tagjai aktívan részt vettek a kérdések megvitatásában. Így a rendezvény sikeresen elérte azt a célját, hogy a különböző szempontokat kiemelő kutatók közösen kezdtek el gondolkozni a területi tőke koncepciójáról.

1. ábra: A területi tőke koncepciója The concept of territorial capital

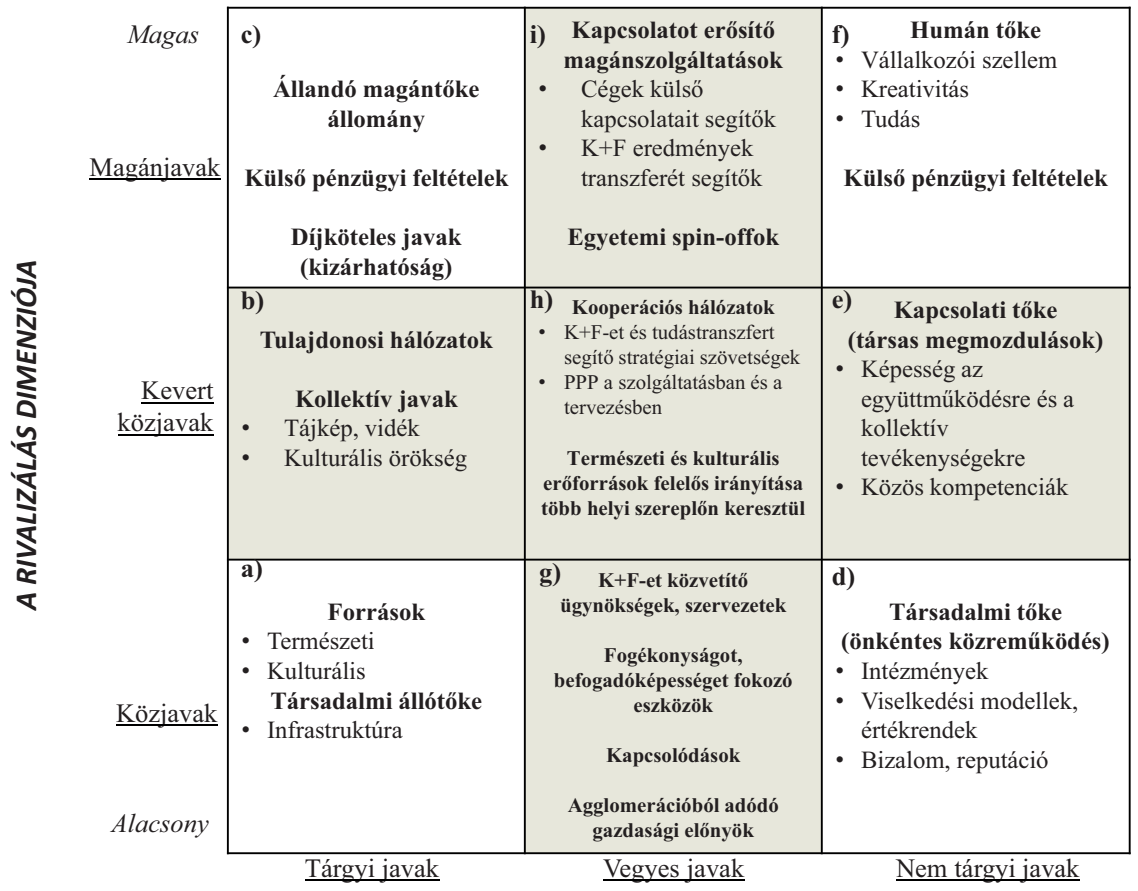

Forrás: Camagni (2008) alapján. 


\section{A területi tőke és a győri modell}

A rendezvény fő előadásaként Rechnitzer János, a Regionális- és Gazdaságtudományi Doktori Iskola vezetője a területi tőke koncepcióját és az innovációs miliő kérdéskörét tárgyalta a győri modell példáján. Az új szempontok bemutatásában kitért az időbeliség kérdésére és az innovációs miliő pontosabb leírásának szükségességére, mivel ezek mutatják egy területrendszer fejlődésének időbeli alakulását. Az előadó kitért a tőketartalmak pontosabb meghatározásának a szükségességére is. Ezek alapján a társadalmi, a kulturális és a gazdasági tőkecsoportok dimenzióit, formáit és funkcióit mutatta be, a bemutatásban megjelent a mikro-, mezo- és makroszint, valamint a formális és informális tényezők csoportosítása. A három tőkecsoport lehetséges kapcsolódási pontjait mutatta be az előadás következő része. A 2. ábrán látható, hogy a tőkecsoportok metszete az innovatív miliő.

Az előadó bemutatta az innovációs kelyhet, amely a területi tőke időbeli alakulására és különféle (történelmi, gazdasági, politikai) időszakokban való megjelenésére, vagyis az innovációs miliők egymásra épülésére, egy terület fejlődési pályájának leírására szolgáló modell (3. ábra).

Végezetül az előadásban a győri ipari körzet kutatásának eredményeit ismerhettük meg, melyben célként jelent meg a városfejlődés új elemzési eljárá-

2. ábra: A tőketípusok lehetséges kapcsolatai Possible relations of different types of capital

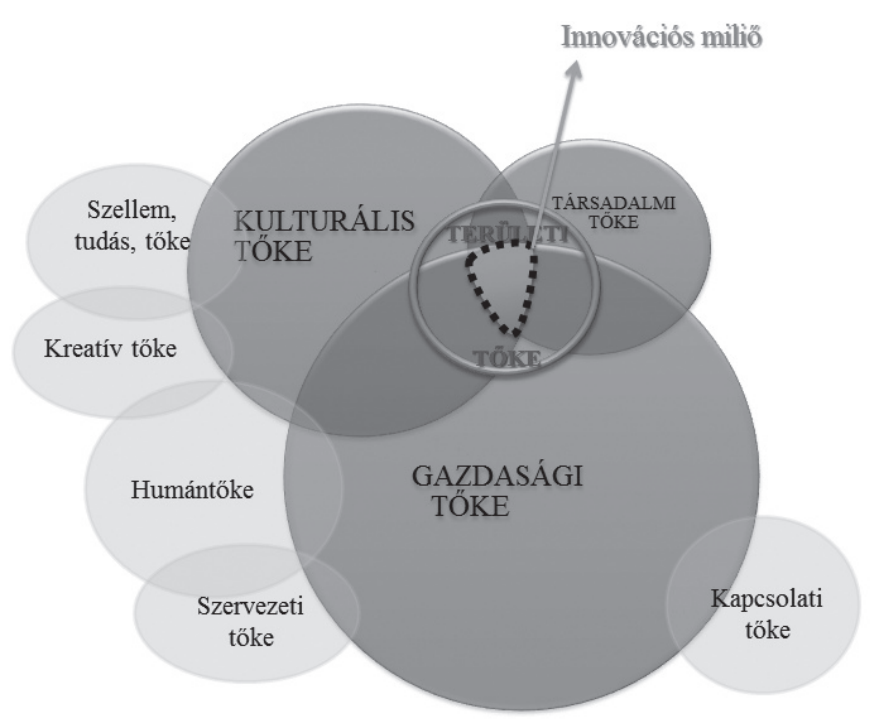

Forrás: Rechnitzer (2015). 
3. ábra: Térségi innovációs kehely és alkotótényezői

The regional innovation chalice and its components

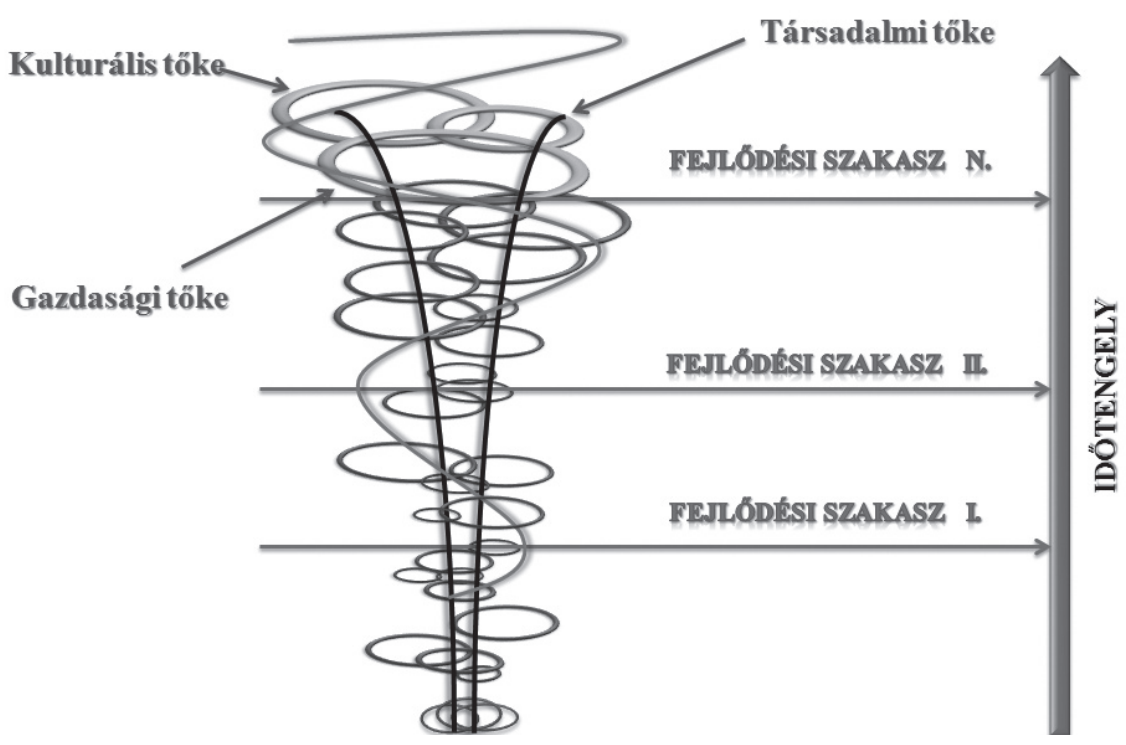

Forrás: Rechnitzer (2015).

sának kidolgozása és azon komplex tényezők kiemelése, amelyek a városfejlődést mozgatják. A kutatás során a győri innovációs miliő hat fö fejlődési stációját határozták meg, és azokat azonos szempontok szerint írták le és mutatták be.

\section{A koncepcióval kapcsolatos módszerek és néhány kritikai észrevétel}

Tóth Balázs István, a Nyugat-magyarországi Egyetem adjunktusa doktori disszertációját és azóta számos hazai és nemzetközi publikációját írta a területi tőke témakörében (pl. Tóth 2013). A területi tőke aktualitásáról az előadó kiemelte, hogy elméleti szempontból lehetőséget ad arra, hogy a területi fejlettséget meghatározó tényezőket más megközelítés szerint lehessen rendszerezni. Gyakorlati szempontból pedig szükséges feltárni a területi tőke érvényesülési lehetőségeit a területi tervezésben és a stratégiaalkotásban. Ezután az előadó a területi tőke elméletének kialakulásának főbb mozgatórugóit mutatta be, szerinte a területi tőke fogalmának kialakulását az endogén jellegű növekedés elmélete és a pályafüggőség hangsúlyozása, az EU területi felzárkóztatást célzó politikájának kritikája, a fenntarthatósági koncepciók változása és a kínálatoldali megközelítések iránti igény táplálták. Az előadó alapmodellnek nevezte a 


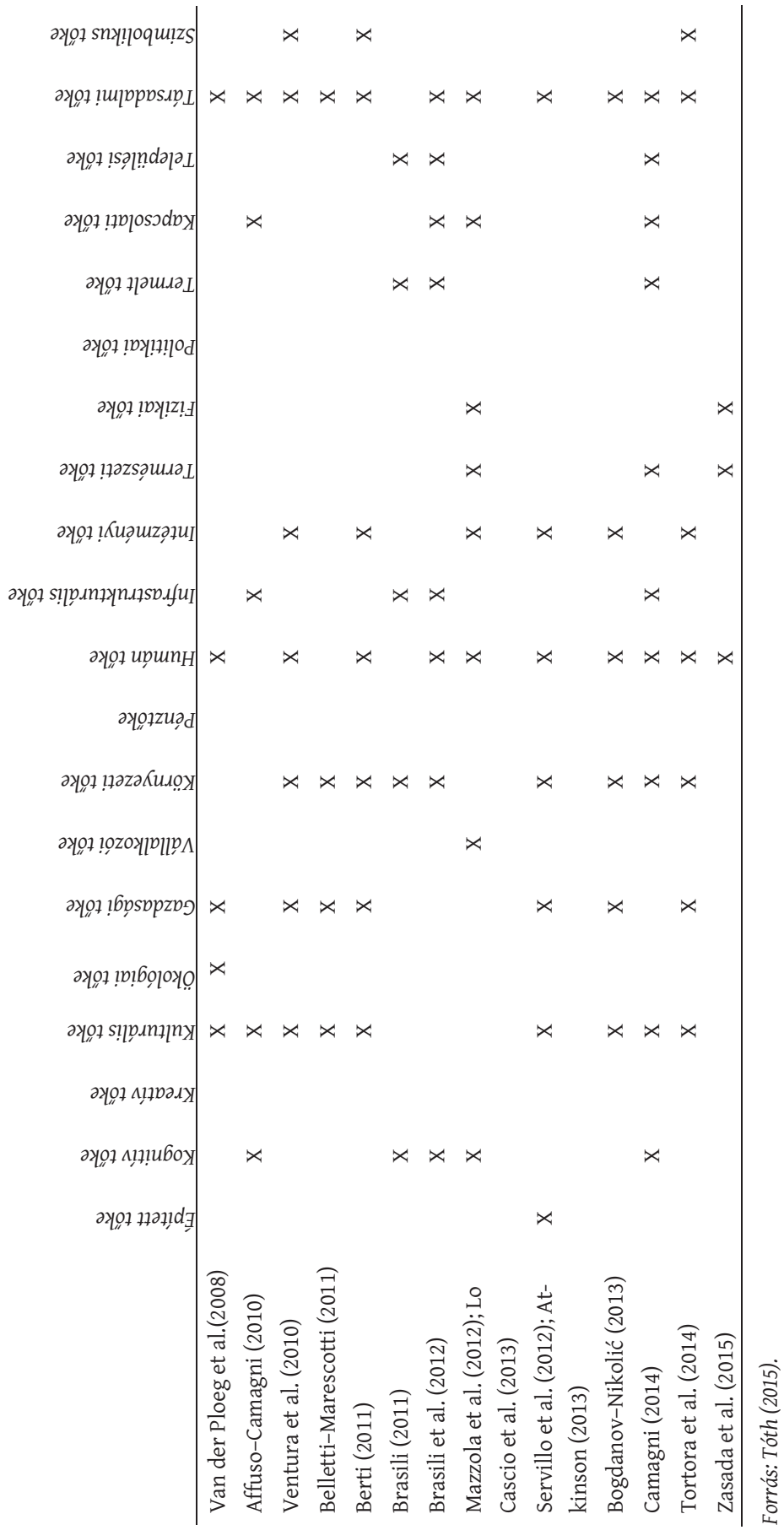


Camagni-féle területitőke-koncepciót és rendszerezve bemutatta azokat a müveket, amelyekben a kutatók rámutatnak a területi tőkére, a tőkefajtákra és a kapcsolódó fogalomkörökre (1. táblázat).

Ezután a területitőke-kutatások főbb jellemzőinek összefoglalását ismerhettük meg a szerzők, az alkalmazott módszer és az esettanulmány területi és időbeli vonatkozása alapján. Ezek alapján az előadó összegyűjtötte a vizsgálatokban mért mutatócsoportokat, majd e szempontok alapján osztályozta a magyar középvárosokat. Az előadás a koncepcióval kapcsolatos kritikai észrevételek bemutatásával zárult. Ennek során kérdésként merült fel, hogy a területi tőke divatfogalom-e vagy fejlesztési esélyként él majd tovább a regionális tudományban. Előkerült a sztenderd definíció hiányának problematikája: a területi tőke valójában nem definíció, hanem egy térség erőforrásainak felsorolása. A tőkekritériumoknak való megfelelés szempontjából is halhattunk kritikai észrevételeket.

Az előadást követő vita során a résztvevők egyetértettek abban, hogy a területi tőke koncepciójának újdonsága abban rejlik, hogy a térség erőforrásait új rendszerbe foglalja. Mivel azonban a fogalomhoz nem kapcsolódik egységes módszertan és a vele foglalkozó szerzők különböző szempontokat emelnek ki benne vagy más fogalomkörökhöz kapcsolják hozzá, a területi tőke elméleti keretei és a gyakorlat között az összhang hiánya tapasztalható. Ebből adódóan a fogalommal kapcsolatos legizgalmasabb gyakorlati kérdés az, hogy jelen tud-e lenni az elképzelés a helyi gazdaságfejlesztési stratégiákban, és ha igen, akkor milyen mértékben. Ha nem, akkor hogyan tudja minél hatékonyabb módon elősegíteni egy adott terület fejlesztését, a hely egyedi értékeinek kiemelésével és az ehhez kapcsolódó egyedi kutatási módszerek használatával?

\section{Használhatóság és mérhetőség kérdése és továbbgondolása, különös tekintettel az innovatív keresztre, illetve az immateriális tőkeelemekre}

Bodor Ákos és Grünhut Zoltán az MTA KRTK Regionális Kutatások Intézetének kutatói, több hazai és nemzetközi publikációjuk is megjelent a területi tőke témakörében. Előadásuk egy korábbi cikkből indult ki (Bodor, Grünhut 2014). Bevezetőjükben kiemelték a Camagni-féle koncepció innovatív keresztből és az immateriális tőkeelemekből adódó újdonságát. Ezek alapján a koncepciót általánosan értékelték az előadás első részében. Ezután a koncepció kilenc cellájából hat cella (az immateriális és vegyes javak - 1. ábra d-i cellái) vizsgálatával folytatták az előadók. Újdonságként értékelték ezeket az elemeket, mivel olyan együttmüködési hálózatokról van szó, amelyek a köz- és magánszféra partnerségén alapulnak. Intézményi bázisuk vagy organikusan alakul ki, vagy a központi területfejlesztés és a fejlesztéspolitika hozza létre őket. Példaként 
szerepeltek a LEADER-hálózatok és az innovációs rendszerek. Az innovatív kereszt kiemelt cellái után az előadás a társadalmi tőke és a kapcsolati tőke értelmezésére fókuszált. Az előadók kritikai észrevétele, hogy a társadalmi tőke sokkal összetettebb annál, hogy a hagyományos keresztben a nem materiális cellában helyezkedjen el. A társadalmi tőke dimenzióiban ugyanis vannak formális elemek, melyeket különböző intézmények, szabályok vagy civil szervezetek alkotnak (4. ábra).

A társadalmi tőke problematikája után a területi tőke immateriális elemeivel kapcsolatos elméletek és az azokhoz kapcsolódó módszertanok alapján az előadók egy részösszegzés eredményeit mutatták be. Ezek szerint a „kulturális” (értékek, attitűdök, normák) megközelítés fontos, mégpedig makro- (térség, régió, város) és mikroszempontból (különböző hálózatok, a fejlesztés szempontjából releváns csoportok) egyaránt. A területi tőke eddigi kutatásaiból ezek következetes vizsgálata hiányzik, viszont a Camagni-féle koncepció erénye, hogy az innovatív kereszt elemeit integrálja a területi tőke rendszerébe. Hibája azonban az, hogy kontextusuk nélkül értékeli ezeket az elemeket.

A részösszegzés alapján ajánlásokat hallhattunk az immateriális elemek kutatásához. A javaslat lényege, hogy a kollektív kulturális erőforrások nemcsak az immateriális tőkeelemek kapcsán beszédesek, ugyanis a területi kutatásokban felértékelődő vegyes tőkejavak (kormányzás, partnerségek, hálózatok, együttmüködések stb.) kiaknázhatósága erősen függ az immateriális tényezőktől, tehát a tágabb kulturális környezet nem elválasztható a szűkebben értelmezett miliőtől. A kollektív kulturális erőforrások kutatására alkalmas normatív indikátorkészletet (Sztompka, 1997, 1999) használt az előadópáros. A bizalom kultúrája című el-

4. ábra: A társadalmi tőke dimenziói, formái és funkciói

Dimensions, forms and roles of social capital

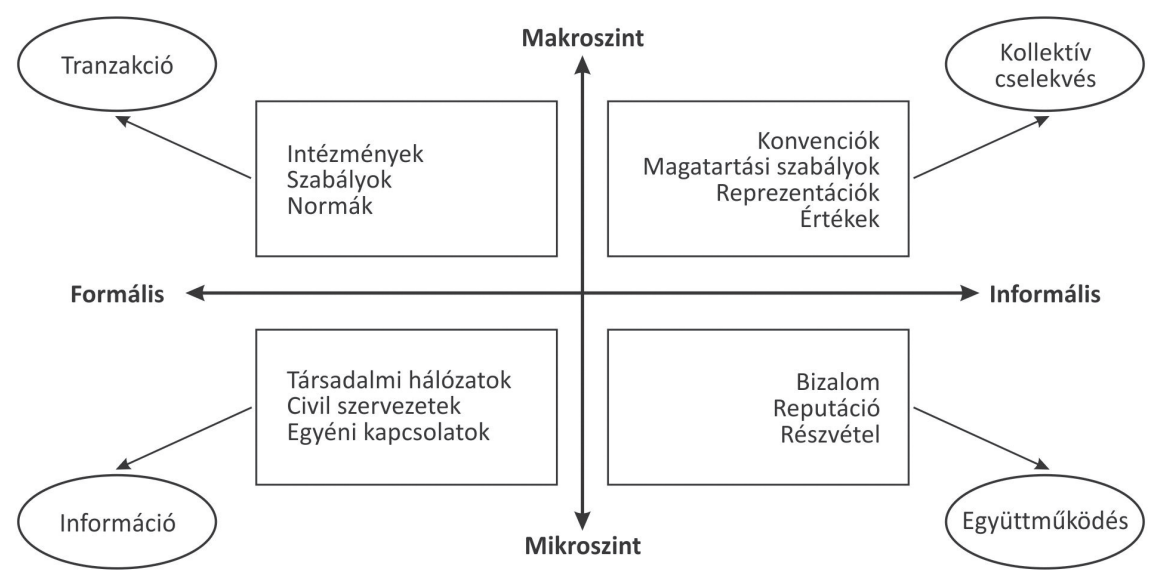

Forrás: Bodor, Grünhut $(2014,8$. 
méletre alapozva követik azt az állítást, miszerint a modern társadalmakban nem az egyének közötti, tapasztalatokon nyugvó személyes bizalom vagy a formális szervezetek felé tanúsított bizalom a fontos, hanem a kollektív informális intézményekbe (társadalmilag elfogadott normák, értékek, szabályok kölcsönös betartásába, attitűdök követésébe) vetett bizalom a döntő. Ez erősíti a társadalmat és a területi tőke immateriális részét. Az immateriális tőkeelemek pontos feltérképezése pedig elengedhetetlen a vegyes tőkejavak szerepének, funkcióinak helyes értékeléséhez. Az előadók szerint a vegyes tőkejavak többsége olyan tényezőket, jórészt fejlesztéspolitikai jelentőségű formális intézményeket ölelnek fel, amelyeknek nem önmagában a meglétük az erőforrás, hanem organikusan kialakuló rendeltetésszerü működésük. Ezek alapján az előadók különböző alapelveket kapcsoltak a területi tőke koncepciójának vegyes javaihoz (2. táblázat).

2. táblázat: A területi tőke vegyes javai és a működésükhöz kapcsolódó alapelvek Club goods of the territorial capital and their systemic principles

\begin{tabular}{|c|c|c|}
\hline $\begin{array}{c}\text { Vegyes javak } \\
\text { (formális intézmények) }\end{array}$ & Alapelvek & Kulturális közeg \\
\hline $\begin{array}{l}\text { Különböző formálisan létező } \\
\text { szervezetek, intézmények: } \\
\text { - K+F transzferszervezetek } \\
\text { - Spin-offok } \\
\text { - Governance típusú formá- } \\
\text { lis együttműködések } \\
\text { - Innovációs ügynökségek, } \\
\text { klaszterek, fejlesztési koa- } \\
\text { líciók, inkubátorok, } \\
\text { LEADER-ek stb. } \\
\text { - Különböző partnerségi } \\
\text { megállapodások } \\
\text { - Direktívák, invenciók, } \\
\text { stratégiák, akciótervek } \\
\text { - ... }\end{array}$ & $\begin{array}{l}\text { - Place-based } \\
\text { - } \text { Szubszidiaritás } \\
\text { - } \text { Decentralizáció } \\
\text { - } \text { Többszintủ kormányzás } \\
\text { - } \text { Bevonás, partnerség, há- } \\
\text { lózatosodás } \\
\text { - Fenntarthatóság } \\
\text { - } \text { Piacelvűség } \\
\text { - Területi, társadalmi ko- } \\
\text { hézió } \\
\text { - Tőke, munkaerő stb. sza- } \\
\text { bad áramlása } \\
\text { - Területi, társadalmi le- } \\
\text { szakadás, marginalizáció, } \\
\text { kirekesztődés megféke- } \\
\text { zése }\end{array}$ & $\begin{array}{l}\text { Korábban kifejtett normatív } \\
\text { értékek, normák és szabá- } \\
\text { lyok rendszere, attitűdök } \\
\text { halmaza }\end{array}$ \\
\hline
\end{tabular}

Forrás: Bodor, Grünhut (2015).

\section{A koncepció újragondolása}

Jóna György, a Debreceni Egyetem Egészségügyi Kar adjunktusa szintén a témában írta doktori disszertációját. A workshopon elhangzott előadás erről és az azóta született tudományos eredményekről szólt (Jóna 2013). Az előadó meghatározta a területi tőke alindexeit (Brasili, Saguatti, Benni, Marchese, 
Gandolfo 2012; Camagni, Dotti 2010), a gazdasági, az infrastrukturális, az intézményi, a társadalmi, a humán, a kapcsolati és a kulturális tőkét. A területi tőke kiszámítása a következőképpen történt: az adatbázis standardizálása után az indikátorokat hét alindexbe (hét tőketípus) sorolta, majd a hét tőketípus számtani átlaga adta meg a vizsgált kistérség adott évi területi tőkéjét. Ezt a számítást mindegyik kistérségre elvégezte Jóna György, és a 174 kistérség területi tőkéjének számtani átlaga adta az országos területi tőkét (Jóna 2015, 106-111.). Az adatokat a „szűk keresztmetszetekért járó büntetés” módszerével korrigálta.

A workshopon kitért arra is, hogy bizonyos kistérségekben kiugróan magas, gyors ütemű területitőke-növekedés volt mérhető 2004 és 2010 között. Első látásra azt gondolhatnánk, hogy a kiugró területitőke-növekedés előnyös, azonban a területi tőke hirtelen, drasztikus mértékű növekedése hosszú távon épp a regionális fejlődés akadályává válhat. A túlfütött és a harmonikus területitőke-növekedés elemzéséhez Kornai János (1972) erőltetett gazdasági növekedésről szóló elméletét adaptálta. Az erőltetett növekedés az egyensúlytalanság egyik fajtája: hosszú távon egy régió gazdasági fejlődése felgyorsul az átlagos növekedéshez és önmaga növekedéséhez képest akár többszörösére. Ez többek között azzal magyarázható, hogy a fejlődést meghatározó területi tényezők egymáshoz viszonyított parciális hatása aránytalan, állandóan és szélsőségesen ingadozik; a régió növekedési potenciálja diszharmonikus. Az eredmények szerint az erőltetett területitőke-növekedés oka, hogy az infrastrukturális háttér rovására fejlesztenek más ágazatokat, és ezzel egy időben nőnek a területi-társadalmi egyenlőtlenségek. A Vásárosnaményi és Ibrány-Nagyhalászi kistérségek esete egyértelműen azt támasztja alá, hogy ha az átlagosnál messze nagyobb területitőke-növekedés mérhető több éven át egy kistérségben, akkor az erőltetett növekedés után a kistérség területi tőkéje alacsonyabb értékre zuhan vissza, mint ahol a növekedés előtt volt.

Jóna György végül hangsúlyozta, hogy a későbbi kutatásokban nagyobb figyelmet kellene szentelni a mutatók kiválasztására, a kvantitatív és kvalitatív eljárások integrálására, valamint a súlyozott és korrigált kompozit indikátorkészlet kialakítására. Ugyanakkor egyetért azokkal az ajánlásokkal is, melyek szerint a területi tőke empirikus elemzését a továbbiakban nem a kistérségek, hanem településegyüttesek vagy városrégiók szintjén lehetne folytatni.

\section{Irodalom}

Bodor Á., Grünhut Z. (2014): Dilemmák a területi tőke modelljének alkalmazhatóságáról. A társadalmi tőke problémája Camagni elméletében. Tér és Társadalom, 3., 3-17.

Brasili, C., Saguatti, A., Benni, F., Marchese, A., Gandolfo, D. (2012): The impact of the economic crisis on the territorial capital of Italian regions. http://www-sre.wu.ac.at/ersa/ersaconfs/ersa12/e120821aFinal00646.pdf (Letöltés: 2012. augusztus 2.) 
Camagni, R. (2008): Regional competitiveness: Towards a concept of territorial capital. In: Capello, R., Camagni, R. Chizzolini, B., Fratesi, U. (eds.): Modelling regional scenarios for the enlarged Europe. Springer, Berlin, 33-47. http://doi.org/cj7qfq

Camagni, R., Dotti, N. (2010): Il sistema urbano. In.: Perulli, P., Pichierri, A. (szerk.): La crisi italiana nel mondo globale. Economia e società del Nord. Einaudi, Torino, 26-41.

Jóna Gy. (2013): A területi tóke kistérségi jellemzői. Doktori értekezés. Szent István Egyetem, Regionális Tudományok Doktori Iskola, Gödöllő.https://szie.hu//file/tti/archivum/Jona_Gyorgy_ertekezes.pdf

Jóna Gy. (2015): Determinants of Hungarian sub-regions' territorial capital. European Spatial Research and Policy, 1., 101-119. http://doi.org/8nk

Kornai, J. (1972): Rush versus harmonic growth. North-Holland Publishing Company, Amsterdam, London

Rechnitzer J. (2015): Területi tőke szerepe a városfejlődésben - A Győr kód. MTA RKK, kézirat, (megjelenés alatt)

RGDI (2015): A Regionális- és Gazdaságtudományi Doktori Iskola küldetése. Széchenyi István Egyetem, Győr http://rgdi.sze.hu/koszonto (Letöltés: 2015. október 8.)

Sztompka, P. (1997): Trust, distrust and the paradox of democracy. WZB Discussion Paper, 97-003

Sztompka, P. (1999): Trust: a sociological theory. Cambridge University Press, Cambridge

Tóth B. I. (2013): A területi tóke szerepe a regionális-és városfejlődésben - esettanulmány a hazai középvárosok példáján. Doktori értekezés. Nyugat-magyarországi Egyetem Széchenyi István Gazdálkodás-és Szervezéstudományok Doktori Iskola, Sopron. http://doktori.nyme.hu/415/19/tothbi_disszertacio.pdf

Tóth B. I. (2015): A Diskurzus a területi tóke koncepcióról c. rendezvényen elhangzott elöadás anyaga. Regionális- és Gazdaságtudományi Doktori Iskola, Széchenyi István Egyetem, Győr 
$\frac{1}{2}$ 